\title{
Kalite Fonksiyon Yayılımı Planlama Matrisinde Kano Modelinin Kullanılması: Akıllı Telefonlar Üzerine Bir Uygulama
}

\author{
Use of the Kano's Model in the Quality Function Deployment Planning Matrix
}

Şeyma DEMIRBAĞ ${ }^{1}$ Ertuğrul ÇAVDAR²

\begin{abstract}
ÖZET
Kano modeli ve Kalite Fonksiyon Yayılımı (KFY) tekniğinin birlikte kullanılması yaklaşımı, farklı ürün özelliklerinin müşterilerin bakış açısından değerlendirilmesinde ve müşteri memnuniyetinin sağlanması için bir işletmenin hangi gereksinimlere öncelik vermesi gerektiği hususunda yol gösterici olma özelliğine sahiptir. Bu çalışmada, Kano modelinin KFY tekniğinde kullanılması yaklaşımı, akıllı telefonlar üzerine yapılan bir uygulama ile incelenmiştir. Çalışmada, ilk olarak müşteri gereksinimleri Kano modeli ile analiz edilerek sınıflandırılmış ve her bir gereksinim ile memnuniyet düzeyi arasındaki ilişki ortaya çıkartılmıştır. Daha sonra, Kano modeli KFY planlama matrisinde kullanılarak öncelikli gereksinimler belirlenmiştir. Kano modelini KFY planlama matrisine dahil etmek için memnuniyet ve memnuniyetsizlik katsayılarının kullanılmasını esas alan bir yöntemden yararlanılmıştır.

Çalışmanın sonuçlarına göre, belirlenen 15 müşteri gereksiniminden 14'ü doğrusal kategoride 1 gereksinim ise heyecan verici kategoride değerlendirilmiştir. İnternet bağlantı türü, kamera özellikleri ve işletim sistemi gereksinimlerinin karşılanmasının memnuniyeti son derece artıracağı, söz konusu gereksinimlerin karşılanmaması ise diğer gereksinimlere oranla daha fazla memnuniyetsizliğe neden olacağı ortaya çıkmıştır. Ayrıca, Kano modelinin KFY tekniğinde kullanılması sonucunda, sırasıyla internet bağlantı türü, kamera özellikleri, işletim sistemi ve dahili hafıza en öncelikli gereksinimler olarak bulunmuştur.
\end{abstract}

Anahtar Kelimeler: Kalite fonksiyon yayılımı, Kano modeli, müşteri tatmini, kalite yönetimi, akıllı telefonlar

\begin{abstract}
The approach of using Kano Model and Quality Function of Deployment (QFD) technique together, provide us with the evaluationof the features of different products from the eyes of customers. Moreover the combination of Kano Model with QFD enables the information about the priority requirements for a business which is seeking customers' satisfaction. In this study, the combination of Kano Model and QFD technique has been analyzed by an application applied on smart phones. In the study, customers' requirements are classified by analyzing with Kano Model and the relationship between the level of satisfaction with each of the requirements is found out. Then, the primary requirements are determined by using Kano Model on QFD planning matrix. In order to use Kano Model on QFD planning matrix a method, in which satisfaction and dissatisfaction coefficients are used, is applied.

According to the results of the study, 14 of totally 15 customer requirements are evaluated in linear category, while 1 requirement is evaluated in exciting category. Internet connection type, camera features and the operating system are the requirements that will extremely increase the satisfaction level, when met. On the other hand, when not met, they will lead much more dissatisfaction compared to other requirements. Additionally, as a result of using Kano Model with QFD technique, Internet connection type, camera features, the operating system and built-in memory are found to be most priority requirements, respectively.
\end{abstract}

Key Words: Quality function deployment, kano model, costumer satisfaction, Quality management, smart phones 


\section{GiRiş}

18. yüzyılın sonlarına doğru başlayan sanayi devrimi ve 20. yüzyılda meydana gelen dünya savaşlarının etkileriyle işletmecilik anlayışı çeşitli evrelerden geçmiştir (Çavdar, 2009). Önce buharlı makinelerin üretimde kullanılmasıyla işletmelerde üretim yönlü bir anlayış başlamıştır. Bu dönemde talebin fazla ve üretimin az olması nedeniyle yöneticilerde «ne üretirsem onu satarım» düşüncesi hakimdir. Dolayısıyla ürünler tüketicilerin istediği gibi değil de işletmelerin istediği şekilde, müşterinin tam olarak ne istediğini ve nasıl istediğini anlamadan üretilmiştir. Ancak daha sonra üretimin hızla artması ve Büyük Ekonomik Kriz (1929-1933)'in yaşanması talebin azalmasına neden olmuştur. Büyük Ekonomik Kriz, ekonominin temel sorunun artık, "üretmek, daha çok üreterek büyümek" olmayıp, üretilenin satılması olduğu bir dönemi başlatmıştır (Mucuk, 2007). Bu nedenle söz konusu dönemde işletmeler satış ve tutundurma çabalarına yönelmişlerdir. Teknolojinin gelişmesi ve talebin azalması yoğun bir rekabet ortamına neden olmuştur. Bu noktadan itibaren, işletmelerin tüketici odaklı üretim yapmaları ve ürün kalitesine önem vermeleri, varlıklarını sürdürebilmeleri açısından bir zorunluluk haline gelmiştir. Bu doğrultuda, yaşanan hızlı teknolojik değişim ve yeniliklerin etkisiyle uzun bir gelişim evresinden geçen ve her geçen gün işletmeler tarafından benimsenen toplam kalite yönetimi anlayışı ortaya çıkmıştır.

Toplam kalite yönetimi, müşteri memnuniyetinin devamlı olarak sağlanması için müşteri isteklerine uygun mal ve hizmetlerin üretilmesi, üretim süreç ve tekniklerinin sürekli iyileştirilmesi ve bunları yaparken de özellikle tüm çalışanlar ile birlikte örgütün bütün kaynaklarının kullanılması ilkelerini esas alan bir yönetim anlayışıdır. Toplam kalite yönetimi anlayışının temel edindiği söz konusu ilkelerin gerçekleştirilmesine yönelik birçok teknik geliştirilmiştir. Bu tekniklerden biri de kalite fonksiyon yayılımıdır.

KFY bir tasarım yaklaşımı olarak 1966 yılında Japonya'da Yoji Akao tarafından sunulmuştur (Akbaba, 2005). Bilinen ilk örnek olay çalışması, 1966 yılında Japonya'da bulunan Bridgestone lastik firmasında gerçekleşmiştir (Tunca ve Bayhan, 2012). Bridgestone Tire şirketinden Oshiumu'nun KFY'nin temel karakteristiklerinden bazılarını içeren süreç güvence şemalarını kullanmaya başlaması, K. Ishikawa'nın KFY'ye benzerlik gösteren "işlerin fonksiyonel göçerimi" düşüncesini geliştirmesi ve Matsushita'nın bunları uygulamaya başlamasıyla KFY kavramı tarihsel olarak Japonya'da biçimlenmeye başlamıştır. Bununla birlikte Yoji Akao, bu yaklaşımın değerini anlayarak ürün tasarım sürecinde bunun gücünden yararlanmak amacıyla, ürün tasarım karakteristiklerini imalat kalite kontrol şemalarında belirli kalite kontrol noktalarına dönüştürme fikrini ortaya atmıştır (Sofyalığlu, 2006). KFY daha sonra Japonya'da Mitsubishi'nin Kobe ağır sanayi limanlarında, işletmenin farklı fonksiyonel birimlerinin katılımıyla çapraz fonksiyonlu üretim gelişim sürecini kolaylaştırmak için kullanılmıştır (Madu, 2000). 1972'de Kobe Limanı müşteri taleplerini yatay eksende, bunları karşılayan metotları da dikey eksende gösteren bir matris kullanmaya başlamışlardır. 1970'lerin sonu ve 1980'lerde Japonlar birçok matris geliş̧tirmişlerdir (King, 1987). Sonrasında süreç, motorlu araçların tasarımlarında kullanılmak üzere Toyota ve tedarikçiler tarafından geliştirilmiştir. Araç Japonya'da elektronik, motorlu araçlar, ev aletleri, giyim ve devreler gibi birçok ürünün tasarım ve üretimini başarılı bir şekilde kontrol etmek için kullanılmaktadır (Munro-Faure ve Munro-Faure, 1993). 1986'da Japon bilim adamları ve Mühendisleri Birliği tarafından yapılan bir araştırma, şirketlerin yarısından fazlasının KFY'nı kullandığını göstermiştir. Toyota otomobil gövdesinin yeni araç modellerinde KFY uygulamasının sonuçlarını uygulayarak başlangıç maliyetlerinde $\% 60$ düşüş başardığı belirtilmiştir (Madu, 2000).

Tekniğin Amerika da kullanımı ise 1986 da Ford ve Xerox, HP, Digital Equipment, Eaton Controls, Texas Instruments gibi şirketlerce kullanılmasıyla başlamıştır. KFY'nın 1986 da Ford'un Tauruz/Sable modelini geliştirme uygulamalarında kullanılması ile birlikte teknik geniş yankı uyandırmıştır. Taurus/Sable programlarına katılan David Muthlier Ford'un, KFY'nı yeni bir ürün için en iyi ürün geliştirme ve sunma aracı olduğunu keşfettiğini söylemiştir. Daha sonra metot Hauser ve Clausing' in makalesiyle büyük bir destek elde etmiştir (Rao vd., 1996).

Avrupa'da ilk KFY Sempozyumu 1992 yilında Ingiltere'de yapılmış, yöntemi uygulayan ilk Avrupalı işletme ise Philips Corporation olmuştur (Akbaba, 2005).

Türkiye'de ilk olarak yöntemin uygulanması 1994 yılına denk gelmektedir. Arçelik firması KFY uygulamasını bu tarihlerde bulaşık makineleri üzerinde yapmıştır (Kılıç ve Babat, 2011). Şirket, 
1995 yılında buzdolabı, çamaşır makinası ve elektrik süpürgesi için de KFY uygulamaları başlatmıştır. Türkiye'de tanınmaya başlaması ile birlikte KFY yöntemini uygulayan işletmelerin sayısı da artmıştır. Tofaş, Cevher Maden Sanayi, BMC, Beko ve Brisa bu yöntemi uygulayan diğer işletmelerden bazılarıdır (Akbaba, 2005).

Kalite fonksiyonu yayılımı müşteri gereksinimlerinin doğrudan yeni ürün özelliklerine dönüştürülmesine yardım eden bir metottur. Bu uygulama ile ürünlerin sadece fonksiyonel ve performans beklentilerini karşılaması değil aynı zamanda yenilikçi veya müşteriler için ekstra cazibe sunan beklenmedik unsurlarında belirlenmesini sağlar. Volvo'nun kalite sorumlusu ve proje yöneticisi Kurt Falk'ın 1993'te birinci Avrupa Taguchi Metotları ve KFY Sempozyumu'nda yaptığı sunumda Japon firmalarının 1970'lerin ortalarından beri KFY'yi başarılı bir şekilde kullandıklarını ve bunun onların çoğu alandaki liderliğini açıkladığını belirtmiştir. Tüm KFY prosedürü, müşteri ihtiyaçlarını tatmin edecek ürünleri sağlayan üretim ölçülerini belirlemek için, ev olarak adlandırılan bir seri matrisi kullanır. Volvo'da dâhil olmak üzere birçok firma tüm sürecin sadece istisnai durumlarda tamamlanmasının üstlenilebileceğini belirtmiş, sadece ilk, bazen ikinci matrisin tamamlanmasının bile kârı artıracağı belirtilmiştir (Sandelands, 1994).

Kalite fonksiyon yayılımı, müşteri isteklerini doğrudan ürün özelliklerine dönüştüren bir tekniktir. Bu teknikte, müşterinin bir üründe istediği, ihtiyaç duyduğu özellikler müşteriden öğrenilerek belirlenir. Bu gereksinimler çeşitli matrisler yardımıyla üretim sürecine aktarılır. Sonuçta müşteri isteklerine uygun malvehizmetlerüretilir. KFY tekniğinin kullanılmasının en önemli avantajları, müşteri isteklerine uygun ürünler üretilmesini garanti altına alması, öncelikli müşteri gereksinimlerinin belirlenmesine yardımcı olması, verimliği artırması, maliyetleri düşürmesi ve rekabet avantajı sağlamasıdır. Ayrıca KFY tekniğinin tüm örgüt çalışanlarının katılımını gerektirir. Bu nedenle, teknik kaynakların daha etkili bir şekilde kullanılmasını da sağlamaktadır.

KFY tekniğinin kullanılmasının temel amacı, müşteri memnuniyeti sağlayacak ürün gereksinimlerini belirlemektir. KFY tekniğinde belirlenen gereksinimlerin memnuniyet düzeyine etkisi aynı kabul edilir. Oysaki her bir gereksinimin memnuniyet düzeyine etkisi farklılık göstermektedir.
$\mathrm{Bu}$ yüzden, hangi gereksinimlerin müşteri memnuniyetini ne düzeyde etkilediğinin bilinmesi önem taşımaktadır. Bu noktada, her bir gereksinimin memnuniyet üzerindeki etkisini ölçmek amacıyla Noritaki Kano tarafından öne sürülen ve Kano modeli diye adlandırılan bir yöntem geliştirilmiştir.

Kano Modeli, belirli bir ürün ve hizmetle ilgili müşteri istek ve ihtiyaçlarının müşteri memnuniyetine aynı oranda katkıda bulunmadığı varsayımıyla ürünle ilgili bu ihtiyaçları temel, doğrusal ve heyecan verici ihtiyaçlar olarak sınıflandırmayı sağlayan bir yöntemdir (Dinçel ve Yenen, 2011). Bir gereksinimin söz konusu kategorilerden hangisine dâhil olduğunun bilinmesi, karşılandığı zaman ne derece bir memnuniyet sağlayacağının ve karşılanmadığı zaman ne ölçüde memnuniyetsizliğe yol açacağının görülmesine imkân sağlar. Temel gereksinimler, bir üründe müşterinin açıkça belirtmediği, karşılanması memnuniyeti fazla etkilememesine rağmen karşılanmaması son derece memnuniyetsizliğe neden olan ürün gereksinimleridir. Doğrusal gereksinimler, karşılandığı zaman memnuniyete karşılanmadığı zaman ise memnuniyetsizliğe yol açan, müşterilerin açık bir şekilde dile getirdiği, üründe bulunmasını istedikleri gereksinimlerdir. Heyecan verici gereksinimler ise, müşterilerin dile getirmediği, karşılanması durumunda yüksek düzeyde memnuniyet sağlayan karşılanmadığında ise memnuniyetsizliğe neden olmayan gereksinimlerdir.

KFG metoduna Kano modelinin dahil edilmesi, müşteriye daha fazla değer katacak ürün ve hizmetlerin geliştirilmesine ve bu sayede müşteri memnuniyetinin ötesine geçerek uzun dönemde müşteri bağlılığının yaratılmasına imkan vermektedir (Dinçel ve Yenen, 2011).

Bu çalışmanın amacı, Kano modeline göre ürün gereksinimlerini sınıflandırmak ve Kano modelini KFY tekniğinde kullanarak öncelikli müşteri gereksinimlerini belirlemektir.

KFY ve Kano modelinin birlikte kullanılmasına yönelik yapılan literatür taramasında akıllı telefonlar üzerine bir çalışmaya rastlanmamıştır. Ayrıca, yapılan araştırmada Türkiye'de söz konusu iki yöntemin bütünleşik olarak ele alınmasına dair yapılan çalışmaların sınırlı olduğu sonucuna varılmıştır. $\mathrm{Bu}$ nedenle çalışma, literatüre katkı sağlaması bakımından önem taşımaktadır. Aynı zamanda, akıllı telefonların artık hayatın vazgeçilmez bir parçası haline gelmiş olması, bu sektörde sürekli yeni 
ürünlerin geliştirilmesi, tüketicilerin gösterdiği yoğun talep de uygulama konusu olarak akıllı telefonların seçilmesinin önemini ortaya koymaktadır. Keza, bu çalışmada, akıllı telefonlar ile ilgili öncelikli müşteri gereksinimlerinin ortaya konması, işletmeler açısından müşteri memnuniyetinin ve dolayısıyla rekabet avantajının sağlanmasında önemli veriler sunmaktadır.

Bu çalışmada, öncelikle Kano modeli ile KFY tekniğinin birlikte kullanılmasına dair literatürde yapılan çalışmalar ele alınmış, daha sonra Kano modelinin KFY tekniğinde, müşteri gereksinimlerinin üretim sürecine yayılmasında önemli verilerin bir kaynağı olan kalite planlama matrisine dahil edilmesi incelenerek, Kano modeli ve KFY'nin birlikte kullanılmasının sağlayacağı yararlar üzerinde durulmuş ve teorik olarak ele alınan bu konular akıllı telefonlar üzerine yapılan bir uygulama ile somutlaştırılmaya çalışılımıştır.

\section{LITERATÜR ÖZETi}

Kano modelinin Kalite Fonksiyon Yayılımı'nda kullanılmasına yönelik çeşitli araştırmalar yapılmıştır. $\mathrm{Bu}$ alandaki ilk araştırmalardan biri Matzler ve Hinterhuber (1998) tarafından yapılmıştır. KFY ve Kano modelinin bütünleşik yaklaşımı kayak sektörü üzerine uygulanmıştır. Uygulamada müşteri gereksinimleri belirlemek için anket yöntemi (Kano anketi) kullanılmıştır. Yaklaşık olarak 1500 kişi ile görüşülmüştür. Anket sonuçlarına göre ürün özelliklerinin hangi kategorilere dâhil edileceğini belirlemek için mod istatistiği kullanılmıştır. Gereksinimlerin önem düzeylerini belirlemek için memnuniyet ve memnuniyetsizlik katsayılarından yararlanılmıştır.

Tan ve Shen (2000), Kano modelinin KFY planlama matrisine dâhil edilebileceğini göstermek için «web sayfası üzerine bir uygulama yapmıştır. Uygulamada, müşteri gereksinimlerinin önceliklendirmek ve önem düzeylerini belirlemek için 5^li skala kullanılarak bir anket yapılmıştır. Ayrıca rekabet analizi için iki rakip seçilmiş ve bu rakiplere göre memnuniyeti ölçmek için yine 5»li skala kullanılarak bir anket yapılmıştır. Çalışmada gereksinimleri Kano kategorilerine göre sınıflandırılmasında hangi yöntemin kullanıldığı belirtilmemiştir.

Tontini (2007), KFY'de Kano modeli entegrasyonu için yeni bira bardağı geliştirilmesi üzerine bir uygulama yapmıştır. Bu çalışmada önerilen yöntemin yararlıı̆ını değerlendirmek amacıyla Kalite Planlama Dersinin lisans öğrencileri tarafından yeni bira bardağı geliştirme çalışması yapılmıştır. Çalışma Brezilya'nın güney kesiminde bulunan Blumenau kentinde gerçekleştirilmiştir. Her gereksinim için önem, memnuniyet ve Kano kategorilerinin belirlenmesi amacıyla 289 kişiden oluşan bir örneklem grubu ele alınmıştır. Kano modeline göre müşteri gereksinimlerini sınıflandırmak için memnuniyet ve memnuniyetsizlik katsayıları kullanılmıştır. Ayrıca memnuniyet katsayıları KFY matrisinde düzeltme faktörleri olarak kullanılmıştır ve dolayısıyla her bir ihtiyacın nispi önem düzeyi bu katsayılara göre belirlenmiştir.

Hsu vd. (2007), Kano modeli ve KFY'yi içeren entegre yaklaşımı kullanarak hizmet kalitesini değerlendirmeye çalışmışlardır. Çalışmada, Tayvan'daki cep telefonu markalarının hizmet kalitesi değerlendirilmiştir. Çalışmada gerekli veriler anket yoluyla toplanmıştır. Müşteri gereksinimlerinin belirlenmesi için ankette 5)li skala kullanılmıştır. Önerilen yaklaşım Nokia markası üzerinde gerçekleştirilmiştir. Rekabet analizi yapabilmek için Samsung ve Motorola markaları rakip olarak seçilmiştir. Çalışmada Kano modelini KFY'ye dahil etmek için Tan ve Shen'in önerdiği yaklaşımdan yararlanılmıştır.

Singh vd. (2011), KFY ve Kano modelinin bütünleşik yaklaşımını göstermek için "web sitesi tasarımı" üzerine uygulama yapmışlardır. Çalışmada, ihtiyaçların hangi Kano kategorilerine dahil edileceğini belirlemek amacıyla memnuniyet ve memnuniyetsizlik katsayılarından yararlanılmıştır. Önem düzeylerini belirlemek için 5'li ölçek kullanılarak anket yapılmıştır.

Hashim ve Dawal (2012), ergonomik ve kullanıcı ihtiyacı açısından okul atölyesinin iş istasyonu tasarımı geliştirmek için KFY ve Kano modeli yöntemlerinin birleşimini önermişlerdir. Bu araştırma, Selangor, Malezya'da bir ortaokulda yürütülmüştür. Mevcut iş istasyonunun sorunlarını tespit etmek için 336 öğrenciye anket yapılmıştır. Toplanan veriler Kano anketine dönüştürülmüş ve 255 öğrenci tarafından yanıtlanmıştır. Daha sonra anket sonuçları kalite evinde kullanılmıştır. Çalışmanın sonunda her iki yöntemin yeni ergonomik şekilde tasarlanmış iş istasyonuna uygulamak için değişiklik unsurlarını önceliklendirilebildiği bulunmuştur. Çalışmada, gereksinimlerin önem düzeyini belirlemek için anket 
yönteminden yararlanılmıştır. Ayrıca çalışmada Kano modelinin KFY ‘ye dahil edilmesi için memnuniyet ve memnuniyetsizlik katsayılarından yararlanılmıştır.

KFY ve Kano modelinin bütünleşik yaklaşımı konusunda Türkiye'de de çalışmalar yapılmıştır. Bu konudaki önemli çalışmalardan biri Sofyalıoğlu ve Tunagil (2012) tarafından gerçekleştirilmiştir. Çalışmada, Kano modelinin KFY planlama matrisi içinde uygun bir dönüşüm fonksiyonu yardımıyla kullanımı, gıda sanayinde süt ve süt ürünleri dalında faaliyet gösteren bir firmada gerçekleştirilen uygulamayla gösterilmiştir. Uygulamayla ilgili olarak firma bünyesinde beş kişiden oluşan KFY takımı belirlenmiştir. Homojenize yoğurtta müşteri intiyaçlarını belirlemek üzere odak grup çalışması yapılmıştır. Diğer gerekli veriler anket yoluyla elde edilmiştir. Anket toplamda 138 kişiye uygulanmıştır. Ayrıca, çalışmada Kano modelinin KFY'ye dahil edilmesi için Tan ve Shen'in önerdiği yaklaşımdan yararlanılmıştır. Çalışmada gereksinimlerin hangi Kano kategorilerine dahil edileceğini belirlemek amacıyla memnuniyet ve memnuniyetsizlik katsayıları kullanıımıştır. Ayrıca rekabet analizi için iki rakip firma seçilmiştir.

Uca ve Menteş (2008), Dokuz Eylül Üniversitesi, Işletme Fakültesi, İşletme Bölümü öğrencilerinin aldıkları eğitim ile ilgili gereksinimlerini sınıflandırıp, önem düzeylerinin analiz edilmesiyle bu alana katkıda bulunmayı amaçlayan bir çalışma gerçekleştirmişlerdir. Çalışmada nitel ve nicel analiz bir arada uygulanmıştır. Öncelikle yapılan odak grup çalışmaları ile gereksinimler ortaya çıkartılmış ve 137 öğrenciye yapılan anketler sonucunda bu gereksinimler Kano Modeli ile sınıflandırılmıştır. Sınıflandırma yapılırken hem istatistiksel mod yönteminden hem de memnuniyet ve memnuniyetsizlik katsayıları kullanılmıştır. Analitik Hiyerarşi Süreci (AHS) kullanılarak sınıflandırılan gereksinimlerin önem düzeyleri belirlenmiştir.

Akyüz vd. (2013), KFY tekniğinde müşteri sesinin daha iyi anlaşılması için Kano modelinden yararlanılması gerektiği belirtilmiş ve Karadeniz Teknik Üniversitesi Orman Fakültesi Orman Endüstri Mühendisliği öğrencilerinin eğitim kalitesine yönelik beklentilerini üzerine bir uygulama yapmışlardır. Çalışmada, Orman Endüstri Mühendisliği Bölümü öğrencilerinin bölüm ve kampüsün fiziki özellikleri, öğretim üyeleri ve derslerden beklentilerinin Kano Modeli ile incelenmesi amaçlanmıştır. Çalışmada, müşteri gereksinimleri odak grup görüşmesi yapılarak belirlenmiştir. Kano Modelinin verileri anket yardımıyla elde edilmiştir. Gereksinimlerin hangi Kano kategorisine gireceğini belirlemek için frekans analizi, memnuniyet ve memnuniyet katsayıları ve bu katsayıların toplamından yararlanılmıştır. Frekans analizinde her bir gereksinimin birinci, ikinci ve üçüncü en sık değerlerine bakılmıştır.

Kılıç ve Delice (2008), KFY'de müşteri gereksinimlerinin daha iyi anlaşılması için Kano modelinin kullanılması gerektiğini belirtmişler ve dijital fotoğraf makineleri üzerine bir uygulama yapmışlardır. Müşteri gereksinimleri Gemba analizi ile belirlenmeye çalışılmıştır. Öncelikle müşteri isteklerinin belirlenmesi için dijital fotoğraf makinesi kullanıcılarından oluşan bir grup ile birlikte odak grup çalışması yapılmıştır. Sonuç olarak belirlenen müşteri istekleri 5 başlık altında toplanmıştır. Bu istekler: fotoğraf makinesinin kolay kullanılabilmesi, fotoğraf kalitesi ve çözünürlüğünün iyi olması, fotoğraf makinesinin çeşitli fonksiyonlarının olması, düşük fiyat özelliğinin olması, taşınabilir olması. Daha sonra 30 kişinin yer aldığı bir anket çalışması yapılarak her bir müşteri isteği için Kano kategorileri belirlenmiştir. Gereksinimlerin hangi kategorilere dahil edileceğini belirlemek amacıyla mod istatistiğinden yararlanılmıştır.

\section{KFY SÜRECI}

Literatürde Kalite Fonksiyon Göçerimi olarak da kullanılan Kalite Fonksiyon Yayılımı́nın İngilizce karşılığı "Quality Function Deployment"dır."Kalite Fonksiyon Yayılımı" teriminin Japonca aslı "Hinshitsu Ki No TenKai" şeklindedir. "Yayılım" kelimesinin Japoncası İngilizcesinden daha geniş bir anlama sahiptir. Japonca'da "yayılım" faaliyetlerin uzatılması ya da genişletilmesi anlamına gelir. Böylece "kalite fonksiyon yayılımı" kaliteli bir öğe üretilmesi için gerekli sorumlulukların şirketin tüm bölümlerine tahsis edilmesi anlamına gelir (Kogure ve Akao, 1983). Yenginol'a (2008) göre KFY, "ürün ya da hizmette, müşterilerin bulunmasını istedikleri ve ihtiyaç duydukları niteliklerin, bu nitelikleri yerine getirecek ya da gerçekleştirecek fonksiyonlara dönüştürülüp, bu fonksiyonları gerçekleştirmesiyle ilgili işleri yapma görevinin örgüt içindeki uygun birimlere aktarılmasıdır."

KFY, "müşteri sesi" nin ürün geliştirmenin Ar$\mathrm{Ge}$, mühendislik ve üretim aşamalarına yayılmış olduğu toplam kalite yönetimi sürecidir (Griffin ve 
Houser, 1993). KFY sürecinde ilk ve en önemli aşama müşterilerin sesinin dilenmesidir. Bu bakımdan KFY'nin temel girdisini, müşterilerin istek ve ihtiyaçları ile ilgili bizzat kendilerinin dile getirdiği, üründen bekledikleri özellikleri ifade eden bilgiler, "müşterinin sesi" ni oluşturur (Çavdar, 2009). Müşterinin sesiyle, üretilecek olan mal ve hizmetlere hem müşterilerin istedikleri nitelikler eklenir, hem de hangi özelliklerin gereksiz olduğu belirlenir. Böylece, hem müşteri tatmininin sağlanmasıyla rekabet avantajı elde edilir hem de gereksiz ürün özelliği için sarf edilen maliyetler azalır.
KFY'nin uygulanması için gerekli ön hazırlıklar yapıldıktan ve müşteriler ile iletişime geçilerek gereksinimleri tanımlandıktan sonra, kalite evinin oluşturulması aşamasına geçilir. Kalite evi, KFY takımı için ürün tasarımı ile ilgili çok önemli bilgileri görüntülemek için kullanılan bir dizi odalardan oluşan matrisler setidir. Tasarımdan üretime kadar gerçekleşen KFY süreci; ürün, parça, süreç ve üretim planlaması olmak üzere birbiriyle bağlantılı 4 matristen oluşur. Bu dört aşamalı model, American Supplier Institute (ASI) modeli olarak da adlandırılır (Tunca ve Bayhan, 2012).

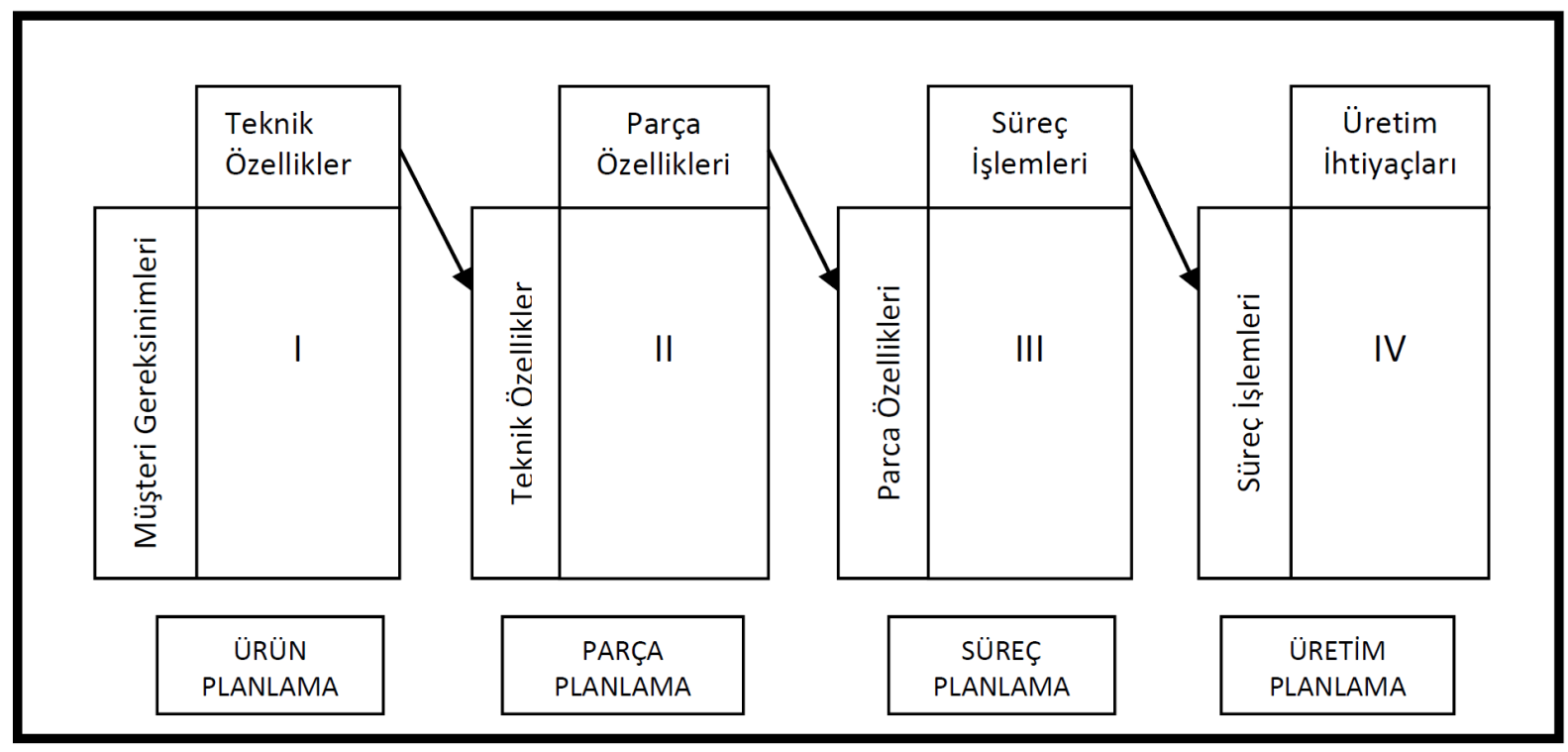

Şekil 1: Müşteri Sesinin Birbiriyle Bağlantılı Matrisler Aracılığıyla Üretime Kadar Aktarılması (Hauser ve Clausing, 1988).

Dört aşamalı modelin birinci aşaması, Kalite evi olarak da adlandırılan ürün planlama matrisinin oluşturulduğu ürün planlama şemasıdır. Kalite evi, bölümler arası planlamanın ve iletişimin gerçekleştirilmesine yarayan araçları sağlayan bir tür kavramsal haritadır. İşletmenin ilgili tüm bölümlerinin katılımıla oluşan bir takım, kalite evi ile pazar araştırmaları ve kıyaslama verilerinden elde edilen müşteri gereksinimlerini yeni mal veya hizmet tasarımı ile karşılanacak uygun sayıdaki önceliklendirilmiş mühendislik hedeflerine veya başka bir ifadeyle teknik özelliklere dönüştürmektedir (Akbaba, 2006).

Özellikle KFY ile ilgili akademik alanda ilk ve en önemli matris olan kalite evi üzerine çalışmalar yapılmakta ve kalite evi oluşturulduktan sonra diğer matrislerin gerçekleştirilmesi işletmelere bırakılmaktadır. Çünkü parça, süreç ve üretim planlama matrisleri işletmelerin teknik tasarımları ve üretim süreçleri ile ilişkilidir. Bu nedenle, söz konusu matrisler işletmelerde tasarım ve üretim teknikleri dikkate alınarak gerçekleştirilmektedir.

KFY sürecinin bir sonraki aşaması olan parça planlama matrisinde, kalite evinde belirlenen önemli teknik karakteristikler veri olarak alınır. Ürün planlama matrisinden elde edilen önemli teknik gereksinimler (mühendislik hedefleri) ile parça karakteristikleri arasındaki ilişkiler belirlenir. Böylelikle, müşteri memnuniyetini sağlamada hangi bileşenlerin öncelikli olduğu saptanmış olur (Tunca ve Bayhan, 2012).

Üçüncü aşama olan süreç planlama aşamasında, ürünün üretilmesi için gerekli süreçleri gösteren bir 
matris oluşturulmaktadır. İkinci matriste yer alan parça özellikleri süreç planlama matrisine aktarılır. Daha sonra, parça özelliklerini etkileyen anahtar süreç operasyonları/süreç parametreleri belirlenir. $\mathrm{Bu}$ matriste, süreç parametreleri parça özellikleri üzerindeki etkilerine göre önceliklendirilir (Akbaba, 2006). Süreç planlama matrisinde amaç, süreçleri tanımlamak ve seçilen parçalar için en uygun süreci belirlemektir (Tunca ve Bayhan, 2012).

Dört aşamalı matris modelinin son matrisi olan üretim planlama matrisinde ise süreç planlama matrisinden alınan temel süreçler ve önem dereceleri bu matrise taşınır. Bu matrisle üretim planlamasını gerçekleştirecek üretim işlemleri ortaya çıkmaktadır (Tunca ve Bayhan, 2012).

Görüldüğü üzere, KFY sürecinin temelini müşteri gereksinimleri oluşturmaktadır. KFY süreci ile müşteri istekleri tasarımdan üretime kadar aktarılmış olur. Bu sayede, üretim sonrasında müşteri isteklerine uygun mal ve hizmetler ortaya çıkarılır.

\section{KANO MODELI}

Kano modeli, müşteri istek ve ihtiyaçlarını, memnuniyet üzerindeki etkisine göre sınıflandıran ve böylece müşteri gereksinimlerinin daha iyi anlaşılmasını sağlayan bir yöntemdir.

Kano Modeli 1984 yılında müşteri ihtiyaçlarını karşılayacak olan ürün/hizmet özelliklerinin sınıflandırılması amacıyla Dr. Noritaki Kano ve meslektaşları tarafından geliştirilmiştir. Kano Modelinin bilimsel alana katkısı, ortaya koyduğu teorik modelin yanında, müşterilerin belirli bir ürün veya hizmetle ilgili sahip oldukları ihtiyaç ve beklentileri memnuniyet düzeyine etkisi açısından sınıflandırmayı sağlayan etkin bir yöntem olmasından kaynaklanmaktadır (Sofyalığlu ve Tunail, 2012).

Tanımlanan bütün müşteri gereksinimlerinin veya müşteri gereksinimlerine karşlık gelen ürün özelliklerinin memnuniyet üzerindeki etkisi aynı değildir. Bazı müşteri gereksinimleri memnuniyet üzerinde oldukça önemli bir etkiye sahipken, bazılarında bu oran daha düşüktür. Işste Kano modeli, hangi müşteri gereksinimlerinin memnuniyeti daha fazla etkilediğini ya da hangi gereksinimlerin üründe bulunmaması durumunda memnuniyetsizliğe yol açtığını belirlemek amacıyla, müşteri gereksinimlerini memnuniyet düzeyine etkisi açısından sınıflandırmaktadır.
Kano, müşterilerin gereksinimlerini ya da mal veya hizmette bulunmasını istedikleri kalite niteliklerini, beklentileri karşılaması ve memnuniyet düzeyindeki etkisine göre temel, doğrusal ve heyecan verici özellikler olarak üç sınıfa ayırmaktadır. Bu üç kalite türünün yanı sıra nötr ve karşıt olmak üzere iki tür daha belirlenebilir. Bunlar gerçek müşteri ihtiyacı olmadığı için karakteristik olarak adlandırılırlar (Chen ve Chuang, 2008).

Temel (Olması Gereken) Özellikler ( $\mathrm{T}$ ): Temel özellikler, bir üründe müşterinin açıkça belirtmediği ancak mutlaka olması gereken temel ihtiyaçlarıdır. Şekilde de görüldüğü gibi, bu ihtiyaçların karşılanması müşteri memnuniyetini artırmazken, bunların karşılanmaması yüksek düzeyde memnuniyetsizliğe neden olacaktır.

Doğrusal Özellikler (D): Müşterilerin açık bir şekilde dile getirdiği, karşılanmasını istediği intiyaçlardır. Şekilden de anlaşılacağı üzere, müşterinin üründe olmasını istediği, açıkça söylediği özelliklerin karşılanması ile memnuniyet arasındaki ilişki doğrusaldır.

Heyecan Verici Özellikler (H): Müşterilerin dile getirmediği, karşılanması için bir beklenti içinde olmadığı ürün özellikleridir. Müşteri, söz konusu özellikleri üründe bulduğunda memnuniyeti çok fazla artacaktır, ancak bu özelliklerin olmaması müşteriyi memnuniyetsizliğe sevk etmeyecektir. Bu özellikler, genellikle rekabet avantajı sağlayabilen müşterilerin o anda farkında olmadığı gizli, gerçek ihtiyaçlarını karşılamaktadır (Florez-Lopez ve Ramon-Jeronimo, 2012).

Nötr özellikler (N): Müşteri için önemli olmayan ürün özellikleridir. Bu özelliklerin üründe bulunması ve bulunmaması memnuniyeti etkilemez.

Karşıt Özellikler (K):Bu özelliklerin performansı yüksekse müşteride memnuniyetsizlik olur. Memnuniyet ile sonuçlanan ürünün performans derecesi düşüktür (Hsu ve diğ., 2007).

Müşteri ihtiyaçları ve bu ihtiyaçları karşılayan ürün özellikleri tanımlandıktan sonra her bir ürün özelliğinin yukarıda belirtilen Kano kategorilerinden hangisine dâhil olduğunu belirlemek amacıyla özel bir anket geliştirilmiştir. Bu ankette, üründe bulunan ve bulunmayan özelliklerle ilgili (ayrı ayrı her bir özellikle ilgili) müşterilere bir çift soru sorulur. Soruların ilki, özelliğin üründe bulunması halinde müşterilerin ne hissedeceği; diğeri ise, özelliğin 
aynı üründe bulunmaması halinde müşterilerin ne hissedeceği yönündedir. Her bir sorunun cevabı için 1- Çok hoşuma gider, 2- Öyle olmasını beklerim,
3-Fark etmez, 4- Hoşlanmam ama katlanabilirim 5Hiç hoşumagitmez şeklinde beş farklı şık sunulur.

Tablo 1: Kano Değerlendirme Tablosu

\begin{tabular}{|c|c|c|c|c|c|c|}
\hline \multirow{2}{*}{\multicolumn{2}{|c|}{ Ürün Gereksinimleri }} & \multicolumn{5}{|c|}{ Olumsuz Soru Formu } \\
\hline & & \multirow{2}{*}{$\begin{array}{c}\text { Hoşlanırım } \\
\text { Ş }\end{array}$} & \multirow{2}{*}{$\begin{array}{c}\begin{array}{c}\text { Öyle } \\
\text { Olmalı }\end{array} \\
H\end{array}$} & \multirow{2}{*}{$\begin{array}{c}\text { Fark Etmez } \\
\mathrm{H} \\
\end{array}$} & \multirow{2}{*}{$\begin{array}{c}\text { Katlanabilirim } \\
\mathrm{H} \\
\end{array}$} & \multirow{2}{*}{$\begin{array}{c}\text { Hoşlanmam } \\
\mathrm{O}\end{array}$} \\
\hline \multirow{5}{*}{ 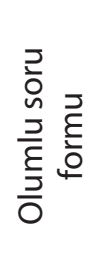 } & Hoşlanırım & & & & & \\
\hline & Öyle olmalı & K & $\mathrm{N}$ & $\mathrm{N}$ & $\mathrm{N}$ & M \\
\hline & Fark etmez. & K & $\mathrm{N}$ & $\mathrm{N}$ & $\mathrm{N}$ & $M$ \\
\hline & Katlanabilirim & K & $\mathrm{N}$ & $\mathrm{N}$ & $\mathrm{N}$ & M \\
\hline & Hoşlanmam & K & $\mathrm{K}$ & $\mathrm{K}$ & $\mathrm{K}$ & Ş \\
\hline
\end{tabular}

Kaynak: (Matzler ve Hinterhuber, 1998).

Kano anketi uygulandıktan sonra anket sonuçlarını değerlendirmek için yukarıdaki Kano değerlendirme tablosunda her bir katılımcının sorunun olumlu ve olumsuz biçimlerine verdikleri yanıtların kesişimine bakılır. Daha sonra, tüm katılımcılardan elde edilen yanıtların sonuçları birbiri üzerine eklenerek frekans tablosu oluşturulur (Sofyalıoğlu, 2006).

Frekans tablosu oluşturulduktan sonra, müşteri gereksinimlerinin hangi kategoriye dahil edileceğini belirlemek için genellikle kategorilerin istatistiksel modlarına bakılır. Bu yönteme göre hangi kategorinin sayısı daha yüksekse ürün özelliği o kategoriye girmiş olur. Bu yöntem bir kategorideki sayının diğer kategorilerdeki sayılara göre belirgin bir şekilde yüksek olduğu durumlarda kullanıldığı zaman daha yararlı olur.

Kano anket sonuçlarına göre bazen kategoriler arasındaki değerler birbirine çok yakın olabilir. Bu durumda, müşteri ihtiyacının hangi kategoriye dâhil edileceği belirsizliğini ortadan kaldırmak için heyecan verici, doğrusal ve temel özelliklerin yayılımı fikrini koruyarak bir çeşit ortalama hesaplanmıştır. Bu ortalamada, iki katsayıya göre frekans tablosundaki veriler azaltılmıştır Bu katsayılar; rekabet ortamında müşteri gereksinimini karşılamanın nispi değeri olan pozitif katsayı ve yine rekabet ortamında müşteri gereksinimini karşılamamanın nispi maliyeti olan negatif katsayısı olarak ifade edilmektedir (Walden, 1993). Pozitif katsayı memnuniyet katsayısı, negatif katsayı ise memnuniyetsizlik katsayısı olarak adlandırımaktadır.
Müşteri memnuniyet ve memnuniyetsizlik katsayıları aşağıdaki formüllerle hesaplanır (Matzler ve Hinterhuber, 1998).

$$
\begin{aligned}
& \text { Memnuniyet Katsayısı }=\frac{H+D}{H+D+T+N} \\
& \text { Memnuniyetsizlik Katsayısı }=\frac{D+T}{(H+D+T+N) \cdot(-1)}
\end{aligned}
$$

Ürün gereksinimi karşılanmadığı zaman bu durumun müşteri memnuniyeti üzerindeki negatif etkisini vurgulamak için müşteri memnuniyet katsayısının önüne eksi işareti konulur. Memnuniyet katsayısı 0 ile 1 arasında değişmektedir. Memnuniyet katsayısının 1'e yakın bir değer olması ürün kalitesinin müşteri memnuniyeti üzerinde büyük etkiye sahip olduğunu gösterirken, memnuniyet katsayısının 0'a yakın bir değer alması, ürün kalitesinin müşteri memnuniyeti üzerindeki etkisinin çok az olduğunu gösterir. Aynı şekilde memnuniyetsizlik katsayısının da dikkate alınması gerekir. Memnuniyetsizlik katsayısının -1'e yakın değer alması, analiz edilen ürün özelliğinin karşılanmamasının müşteri memnuniyetsizliği üzerindeki etkisinin güçlü olduğunu gösterir. Memnuniyetsizlik katsayısının 0'a yakın bir değer alması ise, söz konusu ürün özelliğinin karşılanmamasının müşteri memnuniyetsizliğine neden olmadığını gösterir (Matzler ve Hinterhuber, 1998).

Memnuniyet ve memnuniyetsizlik katsayıları hesaplandıktan sonra ürün gereksinimlerinin hangi kategorilere dahil edilecekleri bir grafik üzerinde gösterilmektedir. 


\section{KANO MODELININ KFY PLANLAMA MATRISINDE KULLANILMASI}

KFY, müşteri sesinin ürün planlama ve tasarım aşamalarına yayılmasını sağlamak için kullanılan çapraz fonksiyonlu bir planlama aracıdır. KFY yeni kavramlar ve teknoloji atılımı fikirlerini teşvik etmek için kullanılır. KFY'nin kullanımı eşzamanlı mühendislik sürecini kolaylaştırır ve müşteri memnuniyetinin sağlanmasında ortak bir hedef doğrultusunda çalışmak için ekibi teşvik eder. Müşteri sesi esas olduğu için, KFY'nin ilk aşamasında, kalite evi her bir müşteri ihtiyacını bir veya daha fazla teknik karakteristiklere dönüştürür. Kalite evinin temel amacı, müşteri ihtiyaçlarını ve ürün için (Ne'ler) ağırlıklarını belirlemek ve daha sonra bu ihtiyaçları teknik karakteristiklere (Nasıl'lar) dönüştürmektir (Hsu ve diğ., 2007).

Müşteri sesini dinlemek, KFY uygulayıcılarının müşterilerin istek ve arzularını elde etmesine yardımcı olmaktadır. Müşteri memnuniyeti KFY'nin nihai hedefidir. Bu nedenle, sadece müşteri sesini dinlemekde yeterli değildir; KFYuygulayıcılarının daha ileri gitmesi gerekir. Yapılması gereken, müşteri sesinin karakteristiklerini derin bir şekilde anlamak ve daha sonra bunlardan yararlı bilgiler elde etmektir. Kano modeli bu noktada müşteri özelliklerini kategorize etmek ve bunların yapısını anlamaya yardımcı olmak için etkili bir yaklaşım sağlar. Böylece KFY'yi daha iyi uygulamak ve müşteri memnuniyetine etkili bir şekilde ulaşmak için KFY ve Kano modeli arasındaki entegrasyonu incelemek gerekir (Tan ve Shen, 2000).

Araştırmacılar, tüm ürün özelliklerinin müşterilere aynı memnuniyet düzeyi vermediğini belirtmişlerdir. Böylece farklı ürün özelliklerini müşterilerin bakış açısından değerlendirmek ve maksimum müşteri memnuniyeti sağlayacak özellikleri birleştirerek analiz etmek şirketler için ciddi bir konu haline gelmiştir. Nitelik gereksinimi ve müşteri memnuniyeti arasındaki doğrusal olmayan ilişki, bazen şirketlerin, tüm gereksinimlerin eşit memnuniyet düzeyi verdiğini varsaymalarına ve böylece müşteri memnuniyetini artırmak için bu niteliklerin geliştirilmesi veya sunulması gerektiği gibi yanlış kararlar vermelerine neden olabilir. Bu nedenle birçok araştırmacı KFY'nin bu dezavantajını ortadan kaldırmak için, müşteri memnuniyeti ve ürün performansı arasındaki doğrusal olmayan ilişkiyi gösteren KFY ve Kano modeli entegrasyonunu önermiş̧irler (Afshan ve Sindhuja, 2013).
Tontini (2007), Kano modelini KFY planlama matrisine dahil etmek amacıyla bir yöntem önermiştir. Bu yöntemde, Kano modelini kalite planlama matrisinde kullanmak için memnuniyet ve memnuniyetsizlik katsayılarından yararlanılmaktadır. Temel KFY yaklaşımında, bütün gereksinimlerin memnuniyeti aynı düzeyde etkilediği kabul edilir. Ancak, memnuniyet ve memnuniyetsizlik katsayıları bir gereksinimin karşılanmasının ve karşılanmamasının memnuniyeti ne ölçüde etkilediğini ortaya koymaktadır. Bu nedenle, KFY tekniğinin söz konusu dezavantajını ortadan kaldırmak ve etkili bir şekilde uygulanabilmesini sağlamak için memnuniyet ve memnuniyetsizlik katsayılarının KFY'de kullanılması faydalı olacaktır.

Tontini (2007) tarafından önerilen yaklaşımda, Kano modelinin KFY tekniğine dahil edilmesi birkaç aşamada gerçekleştirilmektedir.

Illk aşamada, KFYınin temel girdisi olan müşteri gereksinimleri belirlenmektedir. Tanımlanan müşteri gereksinimleri kalite planlama matrisinin ilk sütununa yerleştirilmektedir.

İkinci aşamada, söz konusu gereksinimlerin dahil oldukları Kano kategorileri tespit edilmektedir. Hangi gereksinimin hangi kategoriye gireceğini belirlemek için istatistiksel mod kullanılabileceği gibi memnuniyet ve memnuniyetsizlik katsayılarından da yararlanılabilmektedir. Daha sonra her bir gereksinimin dahil olduğu kategori ikinci sütuna kaydedilir.

Eğer kategorilerin belirlenmesinde istatistiksel mod kullanılmışsa, üçüncü aşama olarak memnuniyet ve memnuniyetsizlik katsayıları hesaplanır. Temel KFY planlama matrisinde her bir gereksinimin önem düzeylerinin belirlenmesi gerekmektedir. Önerilen bu yaklaşımda, planlama matrisindeki önem sütunu aşağıdaki denklemin sonucu ile değiştirilir:

Düzeltme Faktörü= Max $(|S I|,|D I|)$

Burada SI ve DI memnuniyet ve memnuniyetsizlik katsayılarıdır. Düzeltme faktörü veya önem düzeyi, üründe mevcut olduğunda daha fazla memnuniyet sağlayacak, olmadığında ise daha fazla memnuniyetsizliğe neden olacak gereksinimler üzerine daha yüksek ağırlık yükleyen SI ve DI memnuniyet katsayılarından mutlak değeri en yüksek olanı seçilerek belirlenir. Bu durumda, heyecan verici, doğrusal, temel ve nötr gereksinimler, müşterilerde neden olacak memnuniyetin veya 
memnuniyetsizliğin derecesine bağlı olarak dikkate alınmaktadır (Tontini, 2007).

Bu yaklaşımda, bir gereksinimin önem düzeyini belirlemek için anket veya başka bir çalışma yapılmaya gerek duyulmaz. Memnuniyet ve memnuniyetsizlik katsayıları, aynı zamanda gereksinimlerin karşılanmasının ve karşılanmamasının müşteriler açısından önemini belirtmektedir. Yani, bir gereksinimin memnuniyeti ne derece etkilediğinin bilinmesi aynı zamanda bu gereksinimin müşteriler açısından önemini de ortaya koymaktadır.

Seçilen katsayılar planlama matrisinde önem düzeyi sütununa kaydedilir. Son aşamada, her bir gereksinimle ilgi önem düzeyi tüm gereksinimlerin önem düzeyleri toplamına bölünerek nispi önem düzeyi belirlenir. Nispi önem düzeylerinin de eklenmesiyle kalite planlama matrisi tamamlanmış olur. Kano modeli ile bütünleşik KFY yaklaşımına göre, kalite planlama şemasının tamamlanarak nispi önem derecelerinin hesaplanması, bize toplam müşteri memnuniyetinin sağlanması için firmanın üzerinde durması gereken en öncelikli kalemler hakkında fikir vermektedir (Sofyalıoğlu, 2006).

\section{UYGULAMA}

Çalışmanın bu bölümünde, müşteri gereksinimlerinin Kano modeli ile nasıl sınıflandırılacağı ve Kano modelinin KFY planlama matrisine nasıl dahil edileceği akıllı telefonlar üzerine yapılan bir uygulama ile gösterilmiştir.

\subsection{Metodoloji}

Buaraştırmanın amacı, müşterilerin akıllı telefon ile ilgili gereksinimlerini Kano modeli ile sınıflandırmak ve Kano modelini KFY tekniğine uygulayarak öncelikli gereksinimlerini belirlemektir.

Çalışmanın birinci bölümünde KFY tekniği, ikinci bölümünde ise Kano modeli ayrıntıları ile ele alınmıştır. Üçüncü bölümde ise Kano modelinin KFY tekniğinde kullanılabilirliğini göstermek amacıyla akıllı telefonlar üzerine bir uygulama yapıımıştır.

Araştırmanın uygulama kısmı aşağıdaki aşamalar izlenerek gerçekleştirilmiştir.

$\checkmark$ Müşteri gereksinimlerinin belirlenmesi

$\checkmark$ Müşteri gereksinimlerinin Kano modeli ile sınıflandırılması ve analiz edilmesi

$\checkmark$ Kalite planlama matrisinin oluşturulması
Çalışmada müşteri gereksinimlerinin Kano modeli ile sınıflandırılması için veri toplama aracı olarak anket yöntemi kullanılmıştır. Araştırmanın anakütlesini Yüzüncü Yıl Üniversitesi öğrencileri oluşturmaktadır. Ancak anakütlenin tümüne ulaşmak mümkün olmadığından örnekleme yoluna gidilmiştir. Kolayda örnekleme yöntemi kullanılarak çalışmaya 395 öğrenci dâhil edilmiştir.

Çalışmada, Kano anketinin verileri excell programı yardımıyla hesaplanmıştır. Kano anketinin sonuçlarına göre her bir özelliğin hangi kategoriye dâhil edileceği genel olarak memnuniyet ve memnuniyetsizlik katsayılarına göre belirlenmiştir.

Kano modelinin KFY tekniğine dahil edilmesi için Gerson Tontini (2007) tarafından önerilen yaklaşım kullanılmıştır.

Ayrıca, çalışmada Kano anketinin güvenilirliğini test etmek amacıyla güvenilirlik analizi uygulanmıştır. Güvenilirlik analizi sonucunda, elde edilen Cronbach Alpha katsayısı 0,96 olarak bulunmuştur. Alpha katsayısı 0 ile 1 arasında değer almaktadır. Bu değerin 1'e yakın olması, veri toplamada kullandığımız ölçeğin güvenilirliğinin yüksek olduğunu göstermektedir. Dolayısıyla, bu çalışmada kullanılan anketin de güvenilirliğinin yüksek olduğu söylenebilir.

\subsubsection{Müşteri Gereksinimlerinin Belirlenmesi}

Araştırmada, öncelikle müşteri gereksinimleri belirlenmeye çalışılmıştır. Araştırma konusu akıllı telefonlar üzerinde yürütüldüğünden müşteri gereksinimleri daha kapsamlı bilgiler edileceği düşüncesiyle internet üzerinden araştırma yapılarak tespit edilmiştir. KFY'de müşteri sesini dinlemek esastır. Bu nedenle çalışmada uygulanan ankette müşteri gereksinimlerinin belirlenmesine yönelik açık uçlu sorular sorulmuştur. Ancak katılımcılardan cevap alınamamıştır.

Sonuç olarak çalışmada, akıllı telefonlar ile ilgili aşağıda belirtilen 15 müşteri gereksinimi kullanılmıştır:

1. Uygun işletim sistemi

2. Uygun işlemci kapasitesi

3. Uygun kamera özellikleri

4. Uygun ekran boyutu

5. Uygun RAM kapasitesi

6. Uygun dâhili hafıza

7. Uygun İnternet bağlantı türü

8. $3 G$ özelliği 
9. Dokunmatik ekran

10. Görüntülü konuşma

11. Bluetooth

12. Radyo

13. GPS

14. Mp3

15. Klavye

İşletim sistemi türleri genellikle markalar ile bağdaştırılmaktadır. Ancak bu çalışma, herhangi bir marka üzerinden yürütülmediğinden işletim sistemi türü seçilmemiştir. İşletim sistemi genel bir ihtiyaç olarak ele alınmıştır.

\subsubsection{Kano Modeli IIle Müşteri Gereksinimlerinin Sınıflandırılması}

$\mathrm{Bu}$ aşamada, belirlenen müşteri gereksinimleri Kano Modeli ile sınıflandırılmıştır. Bu sınıflandırmayı yapabilmek için öncelikle bu çalışmanın ikinci bölümünde gösterilen Kano anketi hazırlanmıştır. Anket toplam 395 kişiye uygulanmıştır.

Çalışmada gereksinimlerin hangi kategoriye gireceğini belirlemek amacıyla memnuniyet ve memnuniyetsizlik katsayılarından yararlanılmıştır. Katsayılara göre gereksinimlerin dahil oldukları kategoriler aşağıda grafik yardımıyla gösterilmiştir.

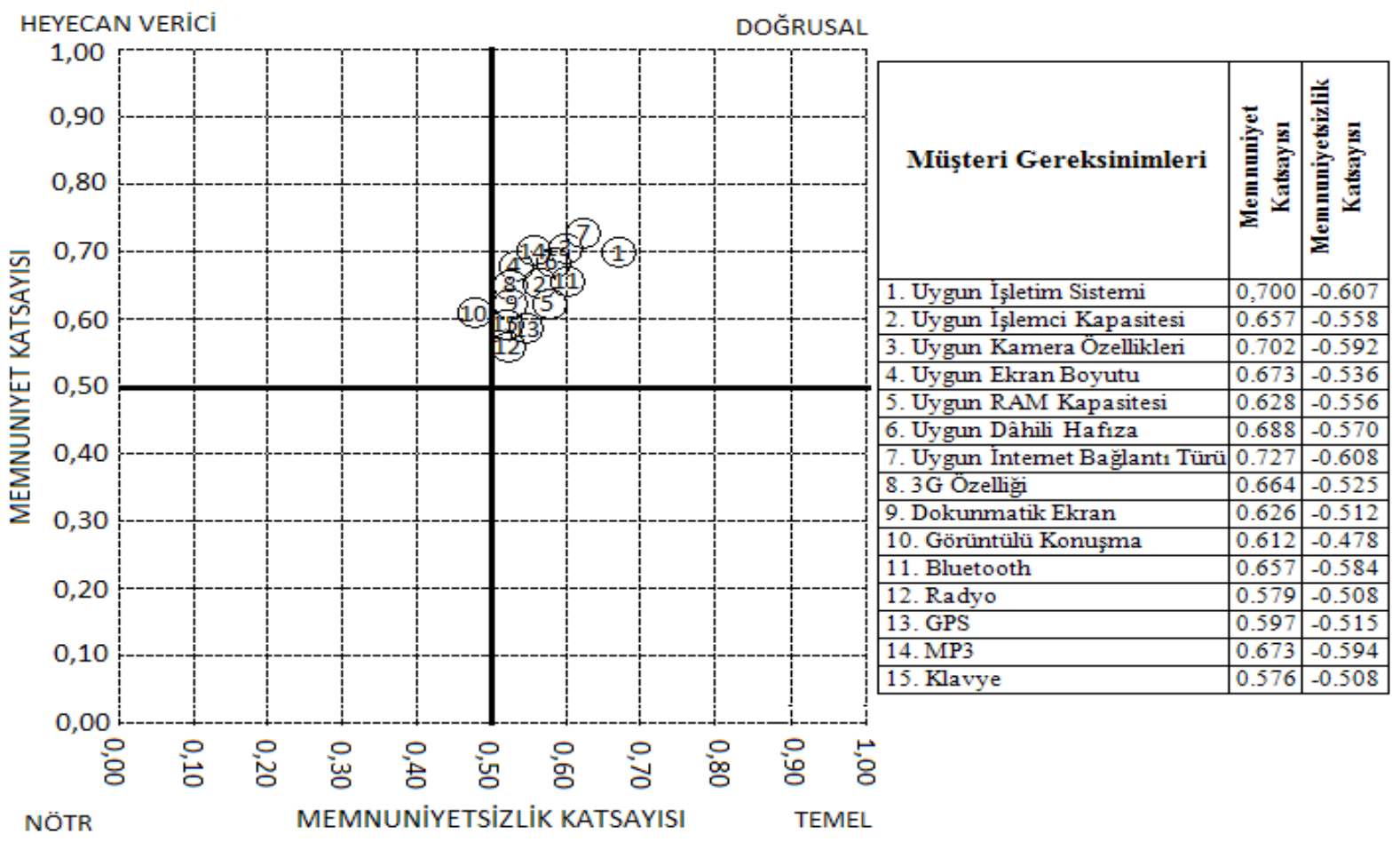

Şekil 2: Memnuniyet ve Memnuniyetsizlik Katsayılarına Göre Gereksinimlerin Dahil Oldukları Kategorilerin Grafik Üzerinde Gösterimi 
Tablo 2: Genel Kano Analizi

\begin{tabular}{|c|c|c|c|c|c|c|c|c|c|c|}
\hline Müşteri Gereksinimleri & $\mathbf{T}$ & D & $\mathbf{H}$ & $\mathbf{N}$ & Ş & $\mathbf{K}$ & $\frac{\text { E }}{\frac{\pi}{0}}$ & 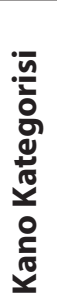 & 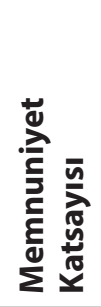 & 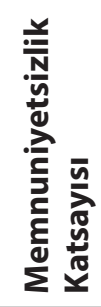 \\
\hline 1. Uygun İşletim Sistemi & 43 & 166 & 75 & 60 & 31 & 20 & 395 & D & 0,700 & -0.607 \\
\hline 2. Uygun İşlemci Kapasitesi & 41 & 161 & 77 & 83 & 21 & 12 & 395 & D & 0.657 & -0.558 \\
\hline 3. Uygun Kamera Özellikleri & 31 & 186 & 71 & 78 & 20 & 9 & 395 & D & 0.702 & -0.592 \\
\hline 4. Uygun Ekran Boyutu & 34 & 163 & 84 & 86 & 15 & 13 & 395 & D & 0.673 & -0.536 \\
\hline 5. Uygun RAM Kapasitesi & 41 & 160 & 67 & 93 & 20 & 14 & 395 & D & 0.628 & -0.556 \\
\hline 6. Uygun Dâhili Hafıza & 30 & 177 & 73 & 83 & 18 & 14 & 395 & $\mathrm{D}$ & 0.688 & -0.570 \\
\hline 7. Uygun İnternet Bağlantı Türü & 26 & 195 & 69 & 73 & 18 & 14 & 395 & D & 0.727 & -0.608 \\
\hline 8. 3G Özelliği & 25 & 168 & 76 & 98 & 17 & 11 & 395 & D & 0.664 & -0.525 \\
\hline 9. Dokunmatik Ekran & 30 & 158 & 72 & 107 & 15 & 13 & 395 & D & 0.626 & -0.512 \\
\hline 10. Görüntülü Konuşma & 30 & 149 & 80 & 115 & 12 & 9 & 395 & $\mathrm{H}$ & 0.612 & -0.478 \\
\hline 11. Bluetooth & 35 & 182 & 62 & 92 & 13 & 11 & 395 & $\mathrm{D}$ & 0.657 & -0.584 \\
\hline 12. Radyo & 35 & 151 & 61 & 119 & 14 & 15 & 395 & D & 0.579 & -0.508 \\
\hline 13. GPS & 39 & 148 & 69 & 107 & 17 & 15 & 395 & $\mathrm{D}$ & 0.597 & -0.515 \\
\hline 14. MP3 & 33 & 184 & 62 & 86 & 18 & 12 & 395 & D & 0.673 & -0.594 \\
\hline 15. Klavye & 34 & 146 & 58 & 116 & 21 & 20 & 395 & D & 0.576 & -0.508 \\
\hline
\end{tabular}

Genel olarak Kano analizi sonuçlarına bakıldığında, müşteri gereksinimlerinin veya ürün özelliklerinin 14'ünün doğrusal kategoride, 1 ürün özelliğinin ise heyecan verici kategoride değerlendirildiği görülebilmektedir.

Ürün özelliklerinin çoğunun doğrusal kategoride değerlendirilmesi, söz konusu özelliklerin karşılanmasının kişileri memnun edeceğini, karşılanmamasının ise memnuniyetsizliğe neden olacağını göstermektedir.

Katılımcılar, görüntülü konuşma özelliğini heyecan verici gereksinim olarak değerlendirmişlerdir. Yani, bu ürün özelliğinin karşılanması, müşteriler de aşırı bir memnuniyet duygusu sağlayacak, karşılanmaması ise memnuniyetsizliğe neden olmayacaktır.

Tabloya memnuniyet ve memnuniyetsizlik katsayıları açısından bakıldığında, internet bağlantı türü (0.727), kamera özellikleri (0.702) ve işletim sistemi (0.700) gereksinimlerinin karşılanmasının memnuniyeti son derece artıracağı görülmektedir. Görüntülü konuşma (0.478), radyoklavye (0.508), dokunmatik ekran (0.512) ve GPS (508) gereksinimlerinin karşılanmamasının ise memnuniyetsizliği çok fazla etkilemediği ortaya çıkmaktadır.

\subsubsection{Kalite Planlama Matrisinin Oluşturulması}

Çalışmanın son bölümünde, müşterigereksinimleri belirlenip Kano analizi ile kategorileştirildikten sonra Kalite Evi için gerekli olan kalite planlama matrisi oluşturulmuştur.

Kalite planlama matrisinde, çalışma herhangi bir mevcut firma üzerinden yürütülmediğinden rekabet analizine yer verilmemiştir.

Çalışmada, müşteri gereksinimlerinin önem düzeylerini belirlemek ve Kano modelini $\mathrm{KFY}$ tekniğine entegre etmek için Gerson Tontini tarafından önerilen memnuniyet ve memnuniyetsizlik katsayılarının planlama matrisine dâhil edilmesi yöntemi kullanılmıştır. 
Tablo 3: Kalite Planlama Matrisi

\begin{tabular}{|c|c|c|c|c|}
\hline No & Müşteri Gereksinimleri & 동 & 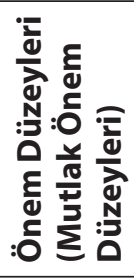 & 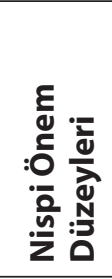 \\
\hline 1 & Uygun İşletim Sistemi & D & 0,700 & 0.0717 \\
\hline 2 & Uygun İşlemci Kapasitesi & D & 0.657 & 0.0673 \\
\hline 3 & Uygun Kamera Özellikleri & D & 0.702 & 0.0719 \\
\hline 4 & Uygun Ekran Boyutu & D & 0.673 & 0.0689 \\
\hline 5 & Uygun RAM Kapasitesi & D & 0.628 & 0.0643 \\
\hline 6 & Uygun Dâhili Hafıza & $\mathrm{D}$ & 0.688 & 0.0704 \\
\hline 7 & Uygun İnternet Bağlantı Türü & $\mathrm{D}$ & 0.727 & 0.0744 \\
\hline 8 & 3G Özelliği & D & 0.664 & 0.0680 \\
\hline 9 & Dokunmatik Ekran & D & 0.626 & 0.0641 \\
\hline 10 & Görüntülü Konuşma & $\mathrm{H}$ & 0.612 & 0.0627 \\
\hline 11 & Bluetooth & D & 0.657 & 0.0673 \\
\hline 12 & Radyo & $\mathrm{D}$ & 0.579 & 0.0593 \\
\hline 13 & GPS & D & 0.597 & 0.0611 \\
\hline 14 & MP3 & D & 0.673 & 0.0689 \\
\hline 15 & Klavye & D & 0.576 & 0.0590 \\
\hline
\end{tabular}

Tabloya bakıldığında, 0,744 nispi önem düzeyi ile internet bağlantı türünün en öncelikli müşteri gereksinimi olduğu görülmektedir. İnternet bağlantı türünü, kamera özellikleri $(0,0719)$ ve işletim sistemi (0.0717) ihtiyaçları izlemektedir. Yine, 0,0704 nispi önem düzeyi ile dâhili hafıza yüksek düzeyde önem verilmesi gereken gereksinimlerden biridir. İşletmeler, özellikle bu gereksinimleri karşıladıklarında büyük ölçüde müşteri memnuniyeti sağlayacaklardır.

\section{SONUÇ VE ÖNERILER}

Çalışmada, yüksek müşteri memnuniyetinin kazanılmasında etkili bir araç olarak kullanılabilen Kalite Fonksiyon Yayılımı tekniği ele alınmıştır. Ayrıca Kalite Fonksiyon Yayılımınınbaşarılı bir şekilde uygulanabilmesine yardımcı olabilen Kano modeli üzerinde durulmuştur.

Kalite Fonksiyon Yayılımı, müşteri istek ve ihtiyaçlarının doğrudan ürün özelliklerine dönüştürülmesini sağlayan bir yöntemdir. Bu yöntemin amacı, en uygun maliyetle müşterilerin istek ve ihtiyaçlarını karşılayarak yüksek düzeyde memnuniyet elde etmektir. Bunun için yüksek düzeyde memnuniyet sağlayabilecek ürün özelliklerinin bilinmesi gerekmektedir.

Kano modeli, müşteri memnuniyeti üzerinde daha fazla etkisi olan ürün özelliklerinin belirlenmesinde kullanılabilen etkili bir yöntemdir. Bu yöntemde, müşteri gereksinimlerinin memnuniyet düzeyini ne derece etkilediği belirlenebilmekte ve her bir gereksinim memnuniyet üzerinde oluşturduğu etkiye sınıflandırılabilmektedir.

Bu çalışmada, Kano modeli aracılığıyla akıllı telefonlar ile ilgili müşteri gereksinimlerinin memnuniyet üzerindeki etkisi ölçülmüş ve bu etkiye göre söz konusu gereksinimler sınıflandırılmıştır. Ayrıca, Kalite Fonksiyon Yayılımı ve Kano modeli yöntemleri birlikte kullanılarak müşterilerin öncelikli gereksinimleri belirlenmiştir. Çalışma, Yüzüncü Yıl Üniversitesiınde yürütülmüştür. Çalışma kapsamına üniversite öğrencileri dahil edilmiş olup gerekli veriler anket yöntemi ile toplanmıştır. Anket 395 kişiye uygulanmıştır. Anket sonuçları analiz edilirken Microsoft Excel programından yararlanılmıştır.

Sonuçlar incelendiğinde, katılımcıların sadece görüntülü konuşma gereksinimini heyecan verici 
bir gereksinim olarak gördükleri, buna karşılık diğer tüm gereksinimlerin doğrusal kategoride değerlendirdikleri ortaya çıkmıştır. Gereksinimlerin memnuniyet üzerindeki etkisi açısından bakıldığında, tüm gereksinimler içerisinde en fazlainternet bağlantı türünün (0.727) memnuniyet sağladığı, klavye gereksiniminin (0.576) ise memnuniyet üzerinde çok az etkisinin olduğu belirlenmiştir. Gereksinimlerin memnuniyetsizlik üzerindeki etkisine bakıldığında, tüm gereksinimler içerisinde internet bağlantı türünün (0.608) yüksek ölçüde memnuniyetsizliğe yol açtığı, görüntülü konuşma (0.478) gereksiniminin ise memnuniyetsizliği çok az etkilediği sonucuna varılmıştır. Ayrıca, planlama matrisi incelendiğinde, internet bağlantı türü, kamera özellikleri, işletim sistemi ve dahili hafıza en öncelikli gereksinimler olarak belirlenmiştir.

$\mathrm{Bu}$ çalışma Van ilinde gerçekleştirilmiştir. Van ilinde akıllı telefon üretimi yapan herhangi bir şirket yoktur. Müşteri sesinin dinlenilmesi aşamasında uygulanan ankette müşteri gereksinimlerinin belirlenmesine yönelik açık uçlu sorular sorulmuştur.
Ancak katılımcılardan uygun cevaplar alınamamıştır. Bu kısıtlar KFY tekniğinin tam olarak uygulanmasında aksaklıklara neden olmuştur. Bu yüzden, gelecekte yapılacak çalışmalarda rekabet analizinin sağlıklı bir şekilde yapılabilmesi ve KFY'nin tüm aşamalarının gerçekleştirilebilmesi için söz konusu kısıtların giderilmesi gerekir. Akıllı telefon üretimi yapan firmalarda KFY tekniği daha etkili bir şekilde uygulanabilir. Müşterilerle odak grup çalışması yapılarak veya akıllı telefon satış noktalarında satıcılar ve müşteriler ile görüşülerek daha sağlıklı sonuçlar elde edilebilir. Ayrıca, akıllı telefonlarla ilgili ürün özelliklerinin hızla değişmesi çalışmanın bir diğer kısıtıdır. Bu çalışmada doğrusal veya heyecan verici kategoride değerlendirilen gereksinimler kısa bir zaman içerisinde temel gereksinimlere dönüşebilir. Ayrıca belirlenen ürün özelliklerinin dışında ileride yeni ürün özellikleri de ortaya çıkabilir. $\mathrm{Bu}$ nedenle, gereksinimler belirli aralıklarla tekrar değerlendirilmeli, yeni ürün özellikleri geliştirilmişse ileride yapılacak çalışmalarda bu gereksinimler de dahil edilmelidir.

\section{KAYNAKÇA}

Afshan, N., Sindhuja, PN., (2013) "Integration of Kano's Model intoQualityFunction Deployment: A Review",The IUP Journal of Operations Management, Vol. XII, No. 2, India, 48-56.

Akao, Y. ve Kogure Masao,(1983) "Quality Function Deployment and CWQC in Japan",Quality Progress, 25-29.

Akbaba, A. (2005), “Müşteri Odaklı Hizmet Üretiminde Kalite Fonksiyon Göçerimi (KFG) Yaklaşımı: Konaklama İşletmeleri için Bir Uygulama Çalışması", Anatolia: Turizm Araştırmaları Dergisi, 16 (1), 59-81.

Akbaba, A. (2006), "Kalite Fonksiyon Göçerimi Süreci'nde Yararlanılabilecek Araçlar ve Yöntemler", Abant İzet Baysal Üniversitesi Sosyal Bilimler Enstitüsü Dergisi, 1 (12), 1-32.

Akyüz K. C., Balaban Y., Yıldırım İ., (2013), “Orman Endüstri Mühendisliği Bölümü Öğrencilerinin Gereksinimlerinin Kano Modeli Yardımıla Sınıflandırılması", Kastamonu Üniversitesi Orman Fakültesi Dergisi, 13(2), 258-267.

Chen, Chun-Chih, Chuang, Ming-Chuen, (2008) "Integrating the Kano Model into a Robust Design Approach to Enhance Customer Satisfaction with Product Design", International Journal of Production Economics 114, 667- 681 .
Çavdar, E., (2009), “Yüksek Öğretimde Hizmet Kalitesi Unsurları ve Bir Uygulama", Niğde Üniversitesi IïBF Dergisi, 2(2), 100-115.

Dinçel K., Yenen V.Z. (23-24 Haziran 2011), “Ürün Pazarlamasında Kalite Fonksiyon Göçerimi (KFG) ve Uygulanabilirliği", XI. Üretim Araştırmaları Sempozyumu, 276-291.

Florez-Lopez Raquel, Ramon-Jeronimo Juan M., (2012) "Managing Logistics Customer Service Under Uncertainty: An Integrative Fuzzy Kano Framework", Information Sciences, (202), 41-57.

Griffin A., Hauser J. R., (1993), "The Voice of the Customer", Marketing Science, ABD, 12(1).

Hashim A. Md, Dawal S. Z. Md, (2012) "Kano Model and QFD Integration Approach for Ergonomic Design Improvement", Malaysia, Procedia-Socialand Behavioral Sciences, 57, 22-32.

Hauser, J. R., Clausing D., (Mayıs-Haziran 1988) "The House of Quality", Harward Business Review, 313

Hsu, C.H., Chang, T. M, Wang, S.Y., Lın, P.Y.,(2007) “Integrating Kano's Model into Quality Function Deployment to Facilitate Decision Analysis for Service Quality", Proceedings of the 8th WSEAS Int. Conference 
on Mathematics and Computers in Business and Economics, Vancouver, June 19-21, Canada, 226-232.

Kılıç, B., Babat D., (2011), "Kalite Fonksiyon Göçerimi: Yiyecek İçecek İşletmelerine Yönelik Kuramsal Bir Yaklaşım", KMÜ Sosyal ve Ekonomik Araştırmalar Dergisi 13 (20), 93-104.

Kılıç Delice, E., Güngör, Z., (2008) "Müşteri İsteklerinin Sınıflandırılmasında Kano Model Uygulaması", Çanakkale On Sekiz Mart Üniversitesi , Akademik Bilişim,193-198.

King, Robert(1987), "Focus/Quality Management Listening to the Voive of the Customer: Using the Quality Function Deployment System", National Productivity Review, 1987, 6/3

Madu, C. N., (2000) House of Quality: QualityFunction Deployment in a Minute, ChiPublishers.

Matzler, K., Hinterhuber, H. H., (1998), "How to Make Product Development Projects More Successful by Integrating Kano's Model of Customer Satisfaction into Quality Function Deployment", Technovation, vol. 18(1), Ingiltere, 25-38.

Mucuk, İsmet, (2007), Temel Pazarlama Bilgileri, 3. Basım, Türkmen Kitabevi, İstanbul.

Munro-Faure Lesley ve Malcolm Munro-Faure,(1993) Implementing Total Quality Management, Pitman Publishing.

Rao, Ashok ve diğerleri (1996), Total Quality Management: A Cross Functional Perspective, John Wiley \& Sons

Sandelands, Eric (1994), “Designing for Customer Satisfaction", Management Decision, 32/5,1994
Singh, A.R, Chaudha, A., Jain R., Mishra, P.K., (2011) "Integration of Kano's Model into Quality Function Deployment (QFD)",Int J Adv Manuf Technol, 53, 1, 689-698.

Sofyalıoğlu, Ç.,(2006) Kalite Fonksiyon Göçerimi ve Gıda Sanayiinde Uygulanabilirliği: Kano Modeli ile Bütünleşik Bir Yaklaşım (Doktora Tezi), Manisa Celal Bayar Üniversitesi, Sosyal Bilimler Enstitüsü

Sofyalıoğlu, Ç. ve Tunail í., (Ocak 2012), "Kano Modelinin Kalite Fonksiyon Göçerimi Planlama Matrisinde Kullanımı", Ege Akademik Bakış, 12(1), 125135.

Tan Kc ve Shen XX, (2000)"IntegratingKano's model in theplanningmatrix of qualityfunctiondeployment", Total Quality Management, 11, 1141-1151.

Tontini, G.,(August 2007), "Integrating the Kano Model and QFD for Designing New Products", Total Quality Management, Vol. 18(6), 599-612.

Tunca, M. Z., Bayhan, M., (2012) "Kalite Fonksiyon Göçerimi Yönteminin Tedarikçi Seçiminde Kullanımı,, Pamukkale Üniversitesi, Sosyal Bilimler Dergisi, 11, 53-69

Uca, M., Menteş, S., (2008)"Işletme Bölümü Öğrencilerinin Bölüm Gereksinimlerinin Kano Modeli ile Sınıflandırılması: Dokuz Eylül Üniversitesi İşletme Fakültesi Uygulaması», İşletme Fakültesi Dergisi, 9(1), 73-91.

Walden, Davit(Ed.), (1993) Center for Quality of Management Journal, V2, N4

Yenginol, F.,(2008) "Neden Kalite Fonksiyon Göçerimi”, Dokuz Eylül Üniversitesi İşletme Fakültesi Dergisi, Cilt 9(1), 7-15. 
